\title{
The Relationship between Emotional Intelligence and Teaching Effectiveness of Lecturers in Public and Private Universities in Malaysia
}

\author{
Siti Asiah Md. Shahid, Syahrina Hayati Md. Jani, Mary Thomas, and Peter Francis
}

\begin{abstract}
This article examines the relationship between emotional intelligence and teaching effectiveness of knowledge workers who are lecturers in public and private universities in Perak, Malaysia. The conceptual framework of this study is based on the model of emotional intelligence (Nelson \& Low, 1998), and the concept of teaching effectiveness (Aregbeyen, 2010). A total of 275 lectures from both public and private were selected as respondents through random sampling technique. Findings indicated that teaching effectiveness was significantly related with all the five components of emotional intelligence at .01 level.
\end{abstract}

Index Terms-Emotional intelligence, teaching effectiveness, knowledge workers, lecturers, higher educational institution.

\section{INTRODUCTION}

In achieving Malaysia's vision 2020 and in sustaining excellence in higher education, lecturers who are considered as knowledge workers must work collaboratively with key stakeholders to foster students' academic growth. As stated by [1] teaching is one of the most stressful occupations, giving impact to mental and physical health of lecturers, hence it is important for lecturers to be emotionally stable with the people they work with. Furthermore, lecturers as knowledge workers must possess emotional intelligence as they experience intense emotion-laden interactions on a daily basis and have a great number of emotional demands compared to most other professionals [2]. Hence, it is crucial for lecturers to be emotionally intelligent because lecturers who lack emotional competence would indirectly affect the overall performance of the universities especially in terms of producing high quality graduates who can fulfill the demands of the industry.

\section{LITERATURE REVIEW}

A university's direction and expansion have been influenced by the increasing social demand for education at all levels [3]. Similarly, from the perspective of human capital, institutions of higher learning in Malaysia provide opportunities to equip individuals with the knowledge, professionalism, and innovation [3]. In other words, lecturers

Manuscript received November 24, 2013; revised March 2, 2014. This work was supported in part by K-Perak Implementation and Coordination Corporation, Malaysia under Grant No. RD0002.

The authors are with the University Technology Mara Perak, Malaysia, 32610 Seri Iskandar, Malaysia (e-mail: sitia348@perak.uitm.edu.my, syahr520@perak.uitm.edu.my, peter034@perak.uitm.edu.my ). as knowledge workers need to be masters of emotional intelligence (EI) as their jobs involve an interpersonal focus when dealing with subordinates, students as well as both internal and external stakeholders. Evidence from research suggests that EI is important to effective worker performance, yet organizations do not address this issue seriously.

The concept of EI according to [4] involves the capacity to reason about emotions and of emotions as well as promoting emotional and intellectual development.

EI was first conceptualized in 1990 by John Mayer and Salovey. According to [4], EI consists of four components which are identifying emotions, using emotions, understanding emotions, and managing emotions. Their model of EI is linked to mental skills and personality traits such as sociability and warmth. Similarly, [5] stresses that intellectual quotient (IQ) accounts to only 20 percent of life's success while 80 percent is attributed to other factors. According to [5], EI is not about IQ but about how well one handles oneself in relationships, how well one works in a team and is able to lead other people. As stated by [4], EI is the ability to recognize one's own feelings and of others, to motivate oneself and to manage one's emotions. EI is critical for lecturers because they have to produce students with first-class mentality. Background of this study is based on the concepts of emotional intelligence by [5] and [6]. According to [5] EI is critical for personal achievement, career success, leadership, and life satisfaction. The four components of EI as proposed by [5] are interpersonal skills, personal leadership skills, self-management, and intrapersonal skills.

According to [5], interpersonal skills involve expressing what is bothering oneself when one is really angry at someone. In the same token, individuals feel comfortable when communicating with a person of authority. In addition, one behaves straightforwardly when making a request from another person and one usually thinks of having fun when around a new group of people.

Ref. [5] define personal leadership skills as having good decision making skills and leadership qualities. In addition, [5] consider good leadership skills as making own decisions independently; making the right decision; seldom regretting the decisions that have been made; and suggesting solutions which other group members accept when involved in a group project. Besides that, personal leadership also entails being persuasive without taking advantage of others; having a good ability to help others solve problems; positively impact others just by being themselves; and putting others at ease in tense situations.

In addition, [5] define self-management as having good time management and commitment ethic. In self- 
management one would receive high ratings in managing one's work if being evaluated in terms of job effectiveness; setting objectives for oneself; organizing one's responsibilities into an efficient personal time schedule; and working effectively on several projects at the same time with good results. Additionally, with self-management skills, one is considered as a dependable person; has a sense of right and wrong; does well in almost any area; and often works day and night on projects to meet a deadline that is set by oneself.

The last component which is intrapersonal involves self-esteem and stress management. The intrapersonal component is defined as feeling very comfortable with oneself as a person; being trustworthy and creative; and accepting one's mistakes rather than being bothered with them. Apart from that, stress management also refers to finding the time to really enjoy life the way one would like it to be, able to comfortably express strong emotions such as fear, anger, and sadness. Furthermore, with intrapersonal skills, one is not under much stress and does not usually push to hurry things up.

Teaching Effectiveness which is based on [6] involves five components which are analytical approach, clarity of teaching, lecturer-group interaction, lecturer-individual student interaction, and enthusiasm of lecturer. According to [6] analytical approach involves lecturer's discussing students' opinions in class; discussing recent developments in the field; presenting facts and concepts from related fields; and emphasizing conceptual understanding. The second component of teaching effectiveness which is clarity of teaching refers to lecturers explaining clearly; being well prepared; answering questions precisely; identifying what is considered important. The next component is lecturer-group interaction. This refers to lecturer's inviting criticism of one's own ideas; inviting students to share their knowledge; knowing if the class understands the lecturer or not; and being concerned with the quality of teaching. The next component, lecturer-individual student interaction refers to being friendly with students; having a genuine interest in students; and is accessible to students out of class. The final component is related to enthusiasm of lecturer and relates to whether the lecturer is an energetic person, having an interesting style of presentation; enjoys teaching with a good sense of humour. With the importance of maximising the potential of human resources in the workplace, this study on EI and teaching effectiveness will definitely enhance the knowledge of EI for knowledge worker professionals especially in human resource development as success of the university and students depend on the lecturers and people in the organization.

\section{RESEARCH QUESTION}

This study seeks to answer whether there is a significant relationship between the identified emotional intelligence and teaching effectiveness in the model.

\section{Methodology}

This study utilized a survey research design using quantitative method. Survey questionnaires were used to collect data from the respondents comprising of lecturers at 2 public universities and 2 private universities in Perak, Malaysia.

There were 54 questions (including demographic items) in this questionnaire. A 48-item survey was designed to obtain information about the lecturers' perceptions on their emotional intelligence and teaching effectiveness while a 6-item question was designed to obtain information about the demographics (gender, age, level of education, university, and length of service) of the sample. To assess the lecturers' emotional intelligence, the Emotional Skills Assessment Process (ESAP), developed by Nelson and Low was utilized. In addition, teaching effectiveness was measured using the self-evaluation of teaching effectiveness (SETE) adapted from Aregbeyen.

In April 8, 2013, 316 questionnaires were distributed to lectures in both public and private universities. Three follow-up calls to the four research organizations were conducted to expedite the rate of returned questionnaires. Finally, 275 respondents returned the completed questionnaires yielding a response rate of 87 percent.

\section{RESUlts}

\section{A. Sample Description}

The data of the completed questionnaire were analyzed using SPSS version 21. Respondents of this study consisted of lecturers from public and private universities. In relation to level of education, the respondents' level of education ranged from Bachelors Degree to $\mathrm{PhD}$. Most of the respondents held a Masters Degree (59.3\%), only 8 percent had a Bachelors Degree while $32.7 \%$ had obtained a $\mathrm{PhD}$ qualification. The biggest proportion of respondents held a Masters Degree because it is the entry level of education for lecturers in both public and private universities. Most of the respondents were female $(52.4 \%)$ while only $47.6 \%$ of the respondents were male. This shows the current situation in most organizations where there is a proportionate number in relation to gender. The number of respondents in University a (public university) was $71(25.8 \%)$ and in University B (public university) was $99(36.0 \%)$. Meanwhile the total number of respondents in University C (private university) was 55 (20.0\%) and University D (private university) was 50 (18.2\%). The demographic data indicates that most of the respondents were from University B (public university) as the total number of faculties in university B (public university) was the biggest compared to other universities in this study. Furthermore, most of the respondents were in the age category of 30 years and below (27.3\%), followed by 31 to 35 years age group. On the other hand, the smallest proportion of respondents was from the age group of 56 years and above $(4.7 \%)$. This demographic data is consistent with the respondents' years of service as most of the respondents had been working with their organization for 5 years or less than 5 years $(43.6 \%)$ and that majority of them were from the younger generation. Therefore, they do not have a lot of working experience. 


\section{B. Correlation between Variables}

This section discusses the findings on the correlation between each component of emotional intelligence and teaching effectiveness for public and private universities. Table I shows the interpretation of the correlation coefficients according to [7]

TABLE I: DESIGNATION OF STRENGTH OF ASSOCIATION BASED ON Size OF CORRELATION COEFFICIENTS

\begin{tabular}{lcc}
\hline \hline \multicolumn{1}{c}{ Strength of Association } & Negative & Positive \\
\hline Weak & -0.29 till -0.10 & 0.10 till 0.29 \\
Moderate & -0.49 till -0.30 & 0.30 till 0.49 \\
Strong & -1.00 till -0.50 & 0.50 till 1.00 \\
\hline \hline
\end{tabular}

\section{Correlation between Each Component of Emotional Intelligence and Teaching Effectiveness (Public University)}

Pearson-Moment correlation was used to determine the relationship among variables in this study. Results displayed in Table II shows that the correlation between all the components of emotional intelligence and teaching effectiveness were significant $(p<0.01)$, weak to strong and positive (Table I). Moving on to Table II, teaching effectiveness was significant, positive, and had a weak correlation with interpersonal $(r=0.194 ; p<0.01)$ and intrapersonal $(r=0.218 ; p<0.01)$; a moderate relationship with personal leadership $(r=0.386 ; p<0.01)$ and a strong relationship with self-management $(r=0.503 ; p<0.01)$. On the other hand, teaching effectiveness has a moderate correlation with overall emotional intelligence $(r=0.481 ; p<$ $0.01)$. This explains that, to a weak extent, an improvement in interpersonal and intrapersonal and to a moderate extent, an increase in personal leadership and overall emotional intelligence and to a very strong extent an increase in self-management is associated with an improvement in teaching effectiveness. In summary, self-management has the strongest association with teaching effectiveness $(r=0.503$; $p<0.01)$ while interpersonal, had the weakest relationship ( $r$ $=0.194 ; p<0.01)$ relationship.

TABLE II: CORRELATION COEFFICIENTS BETWEEN THE FOUR COMPONENTS OF EMOTIONAL INTELLIGENCE AND TEACHING EFFECTIVENESS (PUBLIC UNIVERSITY)

\begin{tabular}{lc}
\hline \hline Components of Emotional & Pearson Correlation Coefficient $(r)$ \\
Intelligence & $0.194^{* *}$ \\
Interpersonal & $0.386^{* *}$ \\
Personal Leadership & $0.503^{* *}$ \\
Self-Management & $0.218^{* *}$ \\
Intrapersonal & $0.481^{* *}$ \\
Overall Emotional Intelligence & \\
\hline \hline
\end{tabular}

** Significant at 0.01

\section{Correlation between Each Component of Emotional Intelligence and Teaching Effectiveness (Private University)}

Results in Table III show that the correlation between all the components of emotional intelligence and teaching effectiveness were significant $(p<0.01)$, weak to strong and positive (Table I). As indicated in Table III, teaching effectiveness was significant, positive, and had a weak correlation with interpersonal $(r=0.230 ; p<0.01)$; a strong relationship with personal leadership $(r=0.538 ; p<0.01)$ with self-management $(r=0.641 ; p<0.01)$ and with overall emotional intelligence $(r=0.633 ; p<0.01)$. In addition, teaching effectiveness was moderately correlated with intrapersonal $(r=0.307 ; p<0.01)$. This shows that, to a weak extent, an improvement in interpersonal and to a moderate extent, an increase in intrapersonal and to a strong extent an increase in personal leadership, self-management and overall emotional intelligence is associated with an improvement in teaching effectiveness. In summary, self-management has the strongest relationship with teaching effectiveness $(r=0.641$; $p<0.01)$ while interpersonal, had the weakest relationship ( $r$ $=0.230 ; p<0.01$ ) which is consistent with the results of public universities.

TABLE III: CORRELATION COEFFICIENTS BETWEEN THE FOUR COMPONENTS OF EMOTIONAL INTELLIGENCE AND TEACHING EFFECTIVENESS (PRIVATE UNIVERSITY)

\begin{tabular}{lc}
\hline \hline Components of Emotional & Pearson Correlation Coefficient $(r)$ \\
Intelligence & $0.230^{* *}$ \\
Interpersonal & $0.538^{* *}$ \\
Personal Leadership & $0.641^{* *}$ \\
Self-Management & $0.307 * *$ \\
Intrapersonal & $0.633^{* *}$ \\
Overall Emotional Intelligence & \\
\hline \hline
\end{tabular}

** Significant at 0.01

\section{DISCUSSION}

Development of quality human capital has been emphasized and highlighted in the $10^{\text {th }}$ Malaysia Plan as a means towards a knowledge-based economy, with higher value-added services and productivity [8]. Hence, this study was conducted in two public and private universities in Perak, Malaysia. The results of this study show that the correlation between teaching effectiveness and self-management for both public and private universities was significant, positive, and strong. This is consistent with the study by [2] but not consistent with that by [9]. These findings reveal that lecturers with self-management generally have good time management skills in dealing with their daily work, in setting priorities and commitment ethic. Additionally, this study reveals that the relationship between teaching effectiveness and interpersonal skills for both public and private universities were significant, positive and the weakest among all the four components of EI. This tally with [2] study but not consistent with [9] study. This means that lecturers need to improve on their interpersonal skills especially their skills of communicating, listening, and working collaboratively with other people. With regard to the relationship between teaching effectiveness and personal leadership, results indicate that the relationship between the two was significant, positive and moderate for public university. This result is similar to both the studies by [2] study and [9]. However, it is not consistent for the private university whereby the correlation between teaching effectiveness and personal leadership was significant, positive and strong. This implies that university lecturers especially public university lecturers need to improve and strengthen their leadership skills especially in decision making so that they are able to guide 
and teach the students effectively and efficiently [10]. The results of this study also indicate that the relationship between teaching effectiveness and intrapersonal skills for private universities was significant, positive, and moderate which is consistent with the study by [2]. Similarly, the relationship between the two was significant, positive and weak for public universities. This shows that university lecturers must improve their self-esteem and must be able to handle stress especially in managing their physical and mental efficiency and individual satisfaction, communicating in personal and work relationships, managing anxiety, controlling as well as managing anger [2]. The present study indicates implications for academics and researchers. Thus, the role of EI in educational environment must be further explored. Lecturers need to understand the role of EI in increasing teaching effectiveness as recent studies on EI is found to predict individual performance and effectiveness at work.

\section{CONCLUSION}

Many researchers agree that traditional measures of intelligence do not really predict success. Since non-cognitive factors are important determinants of work behavior for knowledge workers, universities must focus on training programs for lecturers. Developing EI through training must become an important agenda for important training needs of today's organizations. Hence, emphasis must be given in training lecturers as knowledge workers to be competent in emotional intelligence especially in interpersonal skills, personal leadership skills and intrapersonal skills. With appropriate training, lecturers will be successful at work and will develop as stable individuals in society. Additionally, positive outcomes from the training can contribute towards improved professionalism among lecturers and positive learning environments in the classroom It would also lead to a culture of nurturing continuous improvement to ensure students success and university excellence.

\section{REFERENCES}

[1] Iskandar, R. M. Majzub, and Z. Mahmud, "Kecerdasan emosi dan komitmen pekerjaan dalam kalangan pensyarah universiti di Indonesia," Jurnal Pendidikan (UKM), vol. 34, no. 1, pp. 173-186, 2009.

[2] S. H. M. Jani, "The relationship between emotional intelligence and teaching effectiveness among lecturers at Universiti Teknologi Mara, Puncak Alam, Selangor," M. S. thesis, Universiti Teknologi Mara, Shah Alam, Selangor, 2011.

[3] S. A. M. Shahid, "A study of perceived leadership soft skills, trustworthiness, and structural empowerment of deans in three Malaysian public universities," Ph.D. thesis, Universiti Sains Malaysia, Minden, Malaysia, 2011.

[4] J. D. Mayer, P. Salovey, and D. R. Caruso, "Emotional intelligence: New ability or eclectic traits," American Psychologist, vol. 63, no. 6, pp 503-517, 2008.

[5] D. B. Nelson and G. R. Low, Emotional Intelligence: Achieving Academic and Career Excellence, $2^{\text {nd }}$ ed., New York: Prentice Hall, 2003, pp. 9-13.

[6] O. Aregbeyen, "Students' perceptions of effective teaching and effective lecturer characteristics at the University of Ibadan, Nigeria," Pakistan Journal of Social Sciences, vol. 7, no. 2, pp. 62-69, 2010.

[7] J. Cohen, Statistical Power Analysis for the Behavioral Sciences, $2^{\text {nd }}$ ed., Hillsdale, N. J.: Lawrence Erlbaum Associates, 1988.
[8] Economic Planning Unit, 2010, Ninth Malaysia Plan: 2006-2010, Kuala Lumpur: Percetakan Nasional Malaysia Berhad.

[9] F. F. Hwang, "The relationship between emotional intelligence and teaching effectiveness," Ph.D. dissertation, Texas A\&M University Kingsville, United States, 2007.

[10] H. V. Tang, M. S. Yin, and D. B. Nelson, "The relationship between emotional intelligence and leadership practices: A cross-cultural study of academic leaders in Taiwan and the USA," Journal of Managerial Psychology, vol. 25, no. 8, pp. 899-926, 2009.

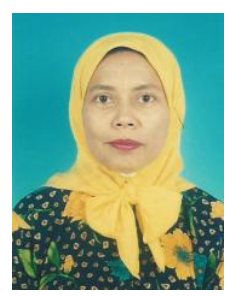

Siti Asiah Md. Shahid holds a diploma in stenography from Institut Teknologi Mara, Dungun, Terengganu, Malaysia which was obtained in 1986. She also obtained her bachelor of education from The University of Toledo, Toledo, Ohio, USA, majoring in business education in 1995; MSc in Education from Virginia Polytechnic Institute and State University, Blacksburg, Virginia, USA, majoring in vocational and technical education in 1997; and $\mathrm{PhD}$ from Universiti Sains Malaysia, Penang, Malaysia, majoring in Educational Leadership and Management in 2011.

She is a senior lecturer at the Faculty of Business Management, Universiti Teknologi Mara, Perak, Malaysia and has also served as head of institute education Development of this institution. She has taught business management subjects including administrative office management, human resource management and organizational behaviour and has served this institution for 26 years. She has written and presented papers on leadership and soft skills.

Her current research includes a study on the relationship between knowledge workers and teaching effectiveness among university lecturers in Perak. Her research fields include leadership soft skills; soft skills in higher education; emotional intelligence; organizational behavior; business and office management and human resource management.

Dr. Siti Asiah Md. Shahid is a lifetime member of Golden Key National Honor Society, USA and also a member of Mara Institute of Technology Academic Staff Association (MITASA), Malaysia

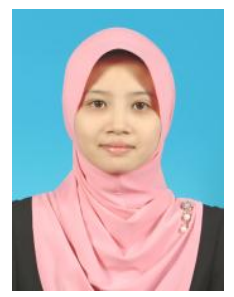

Syahrina Hayati Md. Jani was born on 19 May 1982 in Muar, Johor, Syahrina Hayati did her early and secondary education in Melaka. In year 2000, she gained admission into Universiti Teknologi Mara in Shah Alam, Selangor. She first enrolled for a diploma in office management and technology and later in 2006 went on to pursue a bachelor degree in Office Systems Management.

She worked at Jensepadu Sdn. Bhd. as a personal assistant in Klang, Selangor for a year. She then joined Cosmopoint International College of Technology (CICT) as a lecturer. She then pursued a masters' degree under the young lecturer's scheme and successfully completed her masters in office systems management in 2011. Currently, she works as a lecturer at the Faculty of Business Management, Universiti Teknologi Mara (Perak), Kampus Seri Iskandar, Bandar Seri Iskandar, Perak Darul Ridzuan.

In UiTM (Perak), Ms. Syahrina Hayati has joined the Lead Scholar Group which is an initiative group that is involved in research work. Now, she works together with a group of colleagues to provide consultancy services to KPERAK Implementation and Coordination Corporation.

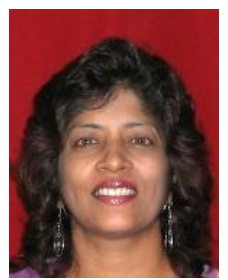

Mary Thomas was born on 20 March 1964 in Slim River, Perak, Mary Thomas did her early and secondary education in Selangor. She holds a bachelor of arts (hons) and a diploma in education from Universiti Kebangsaan Malaysia, Malaysia which was obtained in 1989 and 1990 respectively. She also has a masters degree in teaching of English to speakers of other languages (MSc. TESOL) from the University of Stirling, Scotland obtained in 1996. She is currently pursing a doctorate degree with Universiti Putra Malaysia.

She is a senior lecturer with the academy of Language Studies, Universiti Teknologi Mara(UiTM), Perak, Malaysia and has also served as the tes coordinator of this institution She has taught ESL in UiTM for over 23 years. She has written and presented papers on learning styles and strategies, autonomous learning, communication apprehension and emotional intelligence.

Her current research includes a study on the relationship between knowledge workers and teaching effectiveness among university lecturers in Perak and on the relationship between emotional intelligence and ora communication apprehension and skills among tertiary learners. 
Ms. Thomas is a life time member of Malaysian English Language Teaching Association (MELTA) and ASIA-TEFL member since 2010.

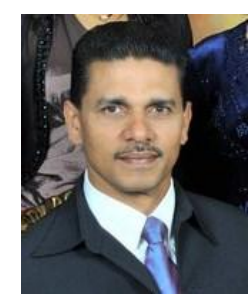

Peter Francis was born on 16 June 1964 in Sitiawan, Perak, Peter Francis did his early and secondary education in Perak. He holds a diploma in ESL from Universiti Malaya in 1996 and a bachelor of edaucation in TESL from Universiti Putra Malaysia, Malaysia which was obtained in 2000. He also graduated with a masters of science degree in teaching of English as a second language. (MSc. TESL) from Universiti Putra Malaysia, Malaysia in
$\mathrm{He}$ is a senior lecturer with the academy of Language Studies, Universiti Teknologi Mara(UiTM), Perak, Malaysia.He has taught ESL in UiTM for over 11 years. Prior to his employment at UiTM, he served as a teacher for 13 years teaching English in schools both at the primary and secondary level. He has written and presented papers on learning styles and strategies, autonomous learning, and using literature in the ESL classroom.

His current research includes a study on the relationship between knowledge workers and teaching effectiveness among university lecturers in Perak and on the relationship between emotional intelligence and oral communication skills among tertiary learners.

Mr. Francis is a life time member of Malaysian English Language Teaching Association (MELTA) and ASIA-TEFL member since 2010. 